\title{
The FleEt as the Basis for Polycrates OF SAMOS' THALASSOCRACY
}

\author{
Jakub Kuciak \\ Jagiellonian University in Kraków
}

\begin{abstract}
Described most exhaustively in Herodotus' Histories, the navy commanded by tyrant Polycrates of Samos was allegedly one of the greatest in archaic Greece, but the extant sources provide conflicting information about its history of use, structure and role in Polycrates' grand strategy. The paper analyses the available evidence to throw light on selected unknowns regarding Polycrates' naval power. Considered matters include numbers and types of ships found in Polycrates' navy: penteconters, triremes and samainae, the invention of the latter type traditionally ascribed to Polycrates. Relevantly to this article, the Greek historiographic tradition frequently ascribes famous inventions to famous personages: within this text, I attempt to untangle this association to test whether it holds true for Polycrates. Finally, I examine how the tyrant obtained funds to maintain his sizeable fleet, investigating whether Polycrates might have resorted to pillaging and privateering to pay for his navy's upkeep.
\end{abstract}

Keywords: Polycrates, Samos, fleet, Herodotus, samaina.

\section{Introduction}

One of the greatest tyrants of the archaic Greece, ${ }^{1}$ Polycrates of Samos stands out in Herodotus' monumental Histories: the historiographer observes that only the famously powerful Syracusan tyrants, Gelo and Hiero I, could rival Polycrates in splendour. ${ }^{2}$ Although the surviving corpus of ancient literature provides a wealth of information on Polycrates (at least in comparison with other shadowy historical figures of the archaic period), historians researching Polycrates' life find virtually every aspect of his activity

1 This paper was written thanks to support from the Polish National Science Centre (UMO-2012/07/B/ HS3/03455). This text is an updated and revised version of an article published in Polish, see Kuciak 2015. For essential information on Polycrates, see e.g.: Lenschau 1952, 1726-1734; Oliva 1954, 142-175; Andrewes 1956, 117-122; Berve 1967, 107-114; Mossé 1969, 15-20; Shipley 1987, 74-99; De Libero 1996, 253-297; Meyer 2012, 80-133; Carty 2015.

2 Hdt. 3.125. 
controversial. ${ }^{3}$ What often attracts scholars of antiquity, classical philologists and historians alike, is the creation and reception of the tyrant's image in the ancient literature. For the creation of Polycrates' legend, Herodotus' Histories remains the most influential account. ${ }^{4}$ Scholars preferring to study material and social history over literature focus on various aspects of Polycrates' policies - both domestic, implemented to control the Samian aristocracy, and foreign, pursued to maintain Samos' uneasy relations with Egypt and Persia, as well as other Greek poleis. ${ }^{5}$ Finally, a subset of scholars studies various naval and shipbuilding enterprises which the tyrant embarked on. Polycrates' international agency depended on maintaining a strong and efficient fleet, the subject of analysis in this article. As in other cases, Herodotus' Histories remains the most informative work on Polycrates' navy: introducing Polycrates (3.39), Herodotus relays that the tyrant had about 100 penteconters at his disposal. A few chapters later, Herodotus mentions 40 triremes, onboard of which Polycrates' political opponents were reportedly sent to Cambyses II. ${ }^{6}$ Critically examining Herodotus' data, I analyse conflicting information about the navy's history of use, its status (public or private), structure and significance in Polycrates' grand strategy. Considered matters include numbers and types of ships found in Polycrates' navy: penteconters, triremes and samainae, the invention of the latter type traditionally ascribed to Polycrates. Relevantly to this article, the Greek historiographic tradition frequently ascribes famous inventions to famous personages: within this text, I attempt to untangle this association to test whether it holds true for Polycrates. Finally, I examine how the tyrant obtained funds to maintain his sizeable fleet, investigating whether Polycrates resorted to pillaging and privateering to pay for his navy's upkeep.

\section{The Status of Polycrates' Fleet}

One of the basic problems concerning the naval force at Polycrates' disposal is its status, i.e. whether it was owned by the Samian polis or consisted of mercenary units; to weigh for or against one of these options, historians have previously examined whether Samos had sufficient naval infrastructure (e.g. boathouses or docks) to support public Samian navy. Philip de Souza rightly noted that, generally speaking, archaic and classical Greek fleets differed in many crucial aspects, one of them being their ownership. Classical

3 What remains unclear is e.g. the chronology of Polycrates' rule. The traditional date of Polycrates' ascendance is 533, as recorded by Eusebius of Caesarea, who stated in his Chronicle: Aput Samum tyrannidem exercent tres fratres Polycrates Sylus et Pantagnostus (Eus. Chron. 185 F Helm). However, available archaeological material and other literary evidence dictates that we should antedate the beginning of Polycrates' rule. The ante quem non date is suggested by Polyaneus' Stratagems in War (1.23), which mentions that another tyrant, Lygdamis of Naxos, helped Polycrates seize power on Samos. Since Lygdamis' rule undoubtedly began in 546, this year also becomes the ante quem non date for the beginning of Polycrates' reign; cf. e.g. White 1954, 36-43.

4 Some of considered topics include the image of Polycrates as a tyrant or as a victim of the divine jealousy, cf. e.g.: Diesner 1959; Gammie 1986; Harrison 2000, 45-47; Katz-Anhalt 2005.

Cf. e.g. Cartledge 1982; Shipley 1987, 91-94; Abramenko 1995.

6 Hdt. 3.145. 
poleis maintained public fleets, whereas archaic fleets were mostly private property, although they could have been commanded by a single leader. ${ }^{7}$ The same scholar also conjectures that Polycrates, an archaic tyrant, precociously maintained a public fleet; ${ }^{8}$ to support his position, de Souza argues that Samos in Polycrates' day already maintained naval infrastructure necessary for operating a public fleet, i.e. boathouses, which, in his reading of Herodotus' words, were constructed for the maintenance of 40 Samian triremes. ${ }^{9}$ De Souza's interpretation cannot be easily accepted or disproved. Herodotus does not link 40 Samian triremes with the Samian boathouses. In chapter 3.44, the historian reports that Polycrates suspected that some men planned to rebel against him, so he pre-emptively sent them on 40 triremes to Cambyses II, whereas at the end of the following chapter Herodotus conveys that wives and children of the banished men were held in the boathouses..$^{10}$ The presence of boathouses for the triremes implies but does not prove that the Samian fleet under Polycrates operated as a public force. Most relevantly, neither archaeological surveys nor other literary accounts provide any data of the said boathouses: faced with the lack of compelling evidence, I remain unsure whether Samos in Polycrates' day had any naval infrastructure or whether Polycrates constructed or owned such infrastructure in the first place. ${ }^{11}$

Despite abovementioned misgivings, Graham Shipley juxtaposes the discussed fragment of Herodotus' Histories with a passage from Strabo's Geography (14.637) discussing the Samian coastline to argue for the existence of boathouses on Samos in Polycrates' times. ${ }^{12}$ Shipley's conjecture cannot be defended: Strabo claims that there was a port with places of anchorage (o $\lambda\lrcorner \mu \eta े v ~ \varepsilon ̌ \chi \omega v ~ v \alpha v ́ \sigma \tau \alpha \theta \mu o v)$ on Samos, but he never links this port with Polycrates, who appears later in Strabo's text. The anchorage likely existed in Strabo's day, but not necessarily in the 6th century BCE. Additionally, one should

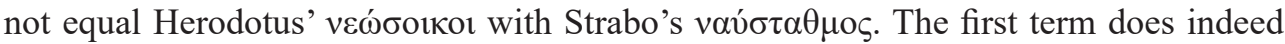
refer to boathouses, i.e. places where ships could be pulled into and repaired. Herodotus mentions that the wives and children of the Samians sent to Cambyses were held within such boathouses - therefore, they must have been permanent buildings. ${ }^{13}$ Hesychius'

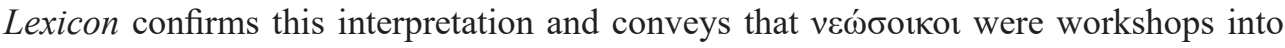

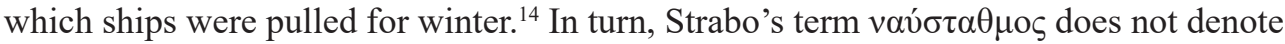

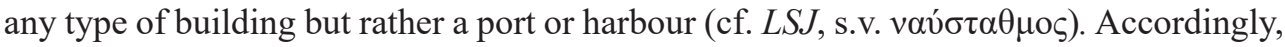
Shipley's hypothesis rests on rather shaky foundations.

7 De Souza 1998, 271-273. The classic state-owned fleet was of course the Athenian naval force, particularly following Themistocles' reforms (cf. Hdt. 7.144; Thuc. 1.93; Plut. Them. 4). For the Athenian fleet before Themistocles' reforms, see Haas 1985. The widespread adoption of state-owned fleets does not mean that private fleets completely disappeared. In his description of the battle of Artemisium, Herodotus mentions Cleinias (the father of Alcibiades), who reportedly participated in the battle at his own expense, with 200 men and his own ship (Hdt. 8.17); cf. also van Wees 2013, 43-45.

8 De Souza 1998, 283; 2008: 43-45.

9 Hdt. 3.45; De Souza 1998, 283.

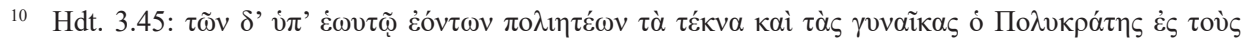

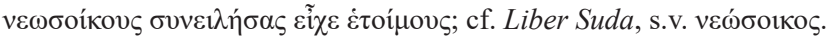

11 Haas 1985, 38.

12 Shipley $1987,76-77$.

13 The word also appears in Thucydides (7.25) and Xenophon (Hell. 4.4).

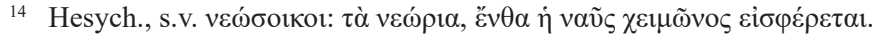


Significantly, neither The Histories nor comparative evidence about other Ionian fleets supports the existence of the Samian state navy, with perhaps the best piece of evidence against its existence found in Herodotus 3.39. Herodotus writes that Polycrates

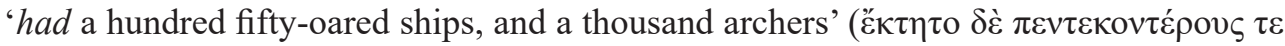

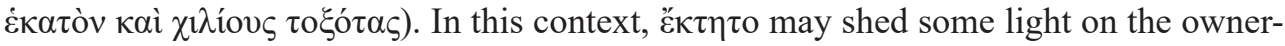
ship of Polycrates' fleet. A plusquamperfectum form of $\kappa \tau$ óo $\mu \alpha 1$, the verb in this tense subtly changes its base meaning to denote possession, ${ }^{15}$ or, in other words, that the ships belonged to Polycrates and not to the state. ${ }^{16}$ As a comparandum, Herodotus employs

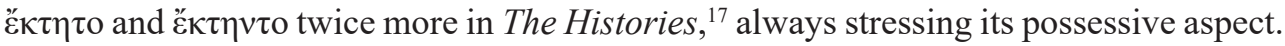

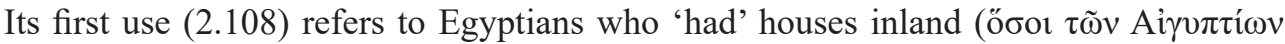

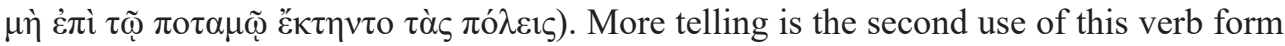
in Book V (5.90), concerning oracles brought to Sparta by King Cleomenes, which had

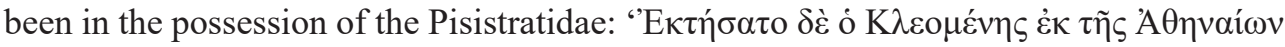

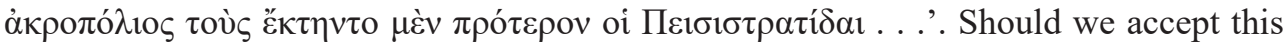

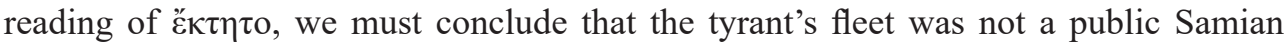
force. As a private navy owner, Polycrates had to man the ships - most probably, with mercenaries, who were readily employed by the Greek and non-Greek rulers alike in the second half of the 6th century and in the preceding period. ${ }^{18}$ Providing the bulk of Polycrates' army and navy personnel, mercenaries in time dominated these forces. ${ }^{19}$ In abovementioned chapter 3.45, Herodotus speaks of a large number of mercenaries in Polycrates' service: having told the story in which the Samians sent to Cambyses supposedly defeated Polycrates, Herodotus expresses his disbelief in such a course of events, partly because the tyrant 'had a great army of hired soldiers and bowmen of his own' ${ }^{20}$ Since the opponents, reportedly, faced off in a sea battle, we can assume that Herodotus means the ship crews when referring to Polycrates' hired soldiers. Considering all the evidence discussed above, it appears likely that Polycrates' fleet depended on mercenaries, aligning with the model later presented by Polybius: the greater a tyrant's ambitions were, the more he had to rely on hired armies. ${ }^{21}$

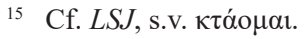

16 Interestingly, the $L S J$ juxtaposes the verb $\chi \rho \tilde{\eta} \sigma \theta \alpha \mathrm{l}$ (denoting, among other significations, 'to use', and often employed in that manner by Herodotus) with its antonym, $\kappa \tau \alpha$ ó $\mu \alpha$ l. These two verbs differ in relation to their connotations: $\kappa \tau \alpha \dot{\alpha} \mu \alpha 1$ refers to owning something, whereas $\chi \rho \tilde{\eta} \sigma \theta \alpha$ r refers only to using something.

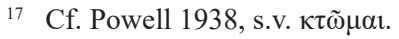

18 Greek mercenaries in the archaic period served under Egyptian pharaohs and rulers of eastern empires: for example, Antimenidas, the older brother of the poet Alcaeus, served in the Babylonian army; cf. Alc. Fr. 48, 350 (Lobel-Page).

19 It is difficult to establish whether Polycrates employed mercenaries from the very beginning of his reign. According to the available sources, the tyrant took over the island with a token force-according to Herodotus (3.120), only 15 hoplites. The historian does not specify whether Polycrates' soldiers were mercenaries. The account of Polyaenus (1.23) provides more detail; he states that Polycrates, his brothers and their supporters took over the Samian acropolis during a festival in honour of Hera. However, Polycrates could have established his rule over the island thanks to the reinforcements sent by Lygdamis, the tyrant of Naxos. Cf. Betalli 1995, 90-91. For the role of mercenaries in the archaic period, see e.g. Luraghi 2006.

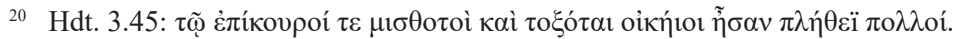

21 Polyb. 11.13. 


\section{The Composition of Polycrates' Fleet}

\subsection{Penteconters and Triremes}

To research the tyrant's naval force we must investigate which types of ships he could have owned in the analysed period. Once again, our evidence comes from the passage from Herodotus' Histories that introduces Polycrates (3.39) and states he had 100 penteconters. The subsequent passage adds that Polycrates possessed 40 triremes (3.44). Furthermore, supplementary written sources and archaeological evidence imply that Polycrates either invented or popularised a type of ship called samaina, a multipurpose vessel with an upturned prow that resembled a boar's head. The following paragraphs discuss the available evidence concerning Polycrates' use of each of these three vessel types.

At the beginning, we should note that surviving literary sources do not offer many helpful details when it comes to distinguishing between specific types of ships built and used in the archaic Greece. Our knowledge of ancient Greek naval terminology comes from the classical period: whenever ancient or modern authors discuss ships of the archaic period, they often retroactively and incongruously apply classical terminology to earlier vessels. This is because no unified naval nomenclature even existed until the classical period, with archaic ship types known under very general names. Our key author, Herodotus, very frequently uses nouns such as ṽ̃ט $\varsigma$ and $\pi \lambda$ oĩov, but he also knows terms

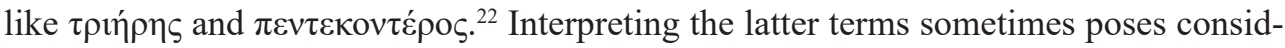
erable difficulties.

Penteconters, very popular and widely used in the archaic Greece, certainly constituted the major part of Polycrates' navy, whereas Herodotus' mention of triremes requires an extended commentary. The archaic Greeks, famous for their shipbuilding skill, built numerous penteconters: allegedly, it were these ships that first carried the seasoned Phocian sailors on their extended sea voyages. ${ }^{23}$ In contrast, the history of trireme in Greece remains murky. Three-banked ships are commonly believed to have been first built outside Greece. ${ }^{24}$ We do not know when they were first used by the Greeks: many scholars doubt that the Greeks sailed them in the archaic period. Ancient writers-most prominently, Thucydides - record that the first triremes have been built in Corinth, ${ }^{25}$ — as many believe, by one Ameinocles, a Corinthian whom Thucydides mentions in the same passage. According to this classical author, the constructor built four ships for the Samians. Since approximately three hundred years divide the life of Ameinocles and the end of the Peloponnesian war as described by Thucydides, the shipwright's activity (and, therefore,

22 Nevertheless, it is worth noting that the name $\tau \rho \imath \rho^{\prime} \eta \varsigma$, first attested in Hipponax, appears in the extant

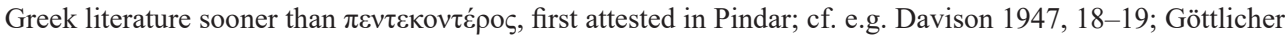
2006; De Souza 2013.

23 Hdt. 1.163; Thuc. 1.13. In the passage about the Phocians' naval accomplishments, Herodotus juxta-

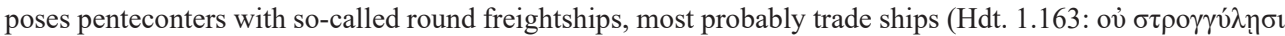

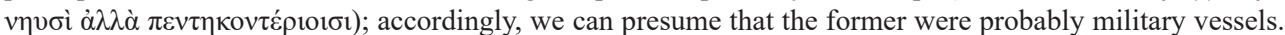
Relevantly, the heyday of the Phocian shipbuilding craft (ca. mid-6th century BCE) concurs with the attested appearance of first warships sensu stricto.

24 De Souza 2013.

25 Thuc. 1.13 . 
the construction of the first trireme) would fall to the early 7th century BCE. Thucydides' statement was uncritically accepted - and misinterpreted - in the older literature on this subject. Ernst Curtius even claimed that the Corinthians used triremes for shipping settlers during the so-called great colonisation. ${ }^{26}$ Even the more recent scholarship occasionally identifies Ameinocles as the constructor of triremes for the Samians, which they supposedly owned already at the turn of the 8 th and 7 th centuries BCE. ${ }^{27}$ Emphatically, Thucydides (1.13) does not name Ameinocles as the inventor of the first trireme, merely mentioning

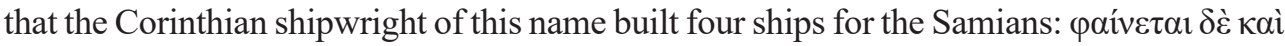

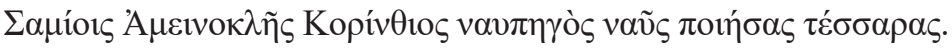

Many have attempted to elucidate Thucydides' words about triremes, particularly to ascertain what type of a vessel he might have had in mind. In his publication Recherches sur les thalassocraties antiques, Jean Pagès identifies triremes with warships designed to escort other merchant vessels on the basis of Thucydides classifying them as a type of vaṽ ${ }^{28}$ Starr correspondingly suggests that this word choice inspired Thucydides' reasoning: [Thucydides - J. K.] identifies the first builder of triremes as Ameinocles of Corinth ... ${ }^{29}$ However, as we noted before in regard to inconsistencies in Greek naval nomenclature, vaṽ $\varsigma$ as a concept has a very wide semantic field and can refer to a number of very different vessels. ${ }^{30}$ Furthermore, Thucydides appears to have distinguished

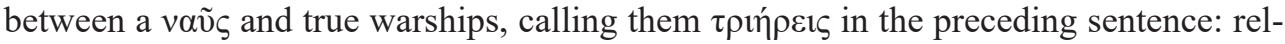

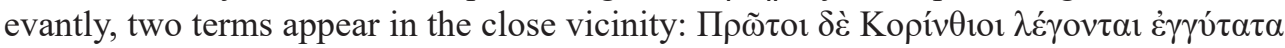

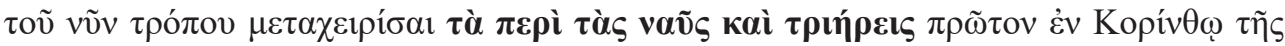
'E $\lambda \lambda \dot{\alpha} \delta$ o $\varsigma \dot{\varepsilon} v v \alpha v \pi \eta \gamma \eta \theta \tilde{\eta} v \alpha l$ ('It is said that the Corinthians were the first to approach the modern style of naval architecture, and that Corinth was the first place in Hellas where galleys were built'; translated by J. M. Dent). ${ }^{31}$ The quoted passage demonstrates quite

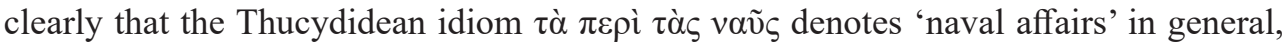
while $\tau \rho \imath \rho^{\prime} \eta \varsigma$ denotes warships. Distinguishing between warships and other vessels, Thucydides used the semantically ambivalent term vaṽ in reference to Ameinocles' vessels. The later authors, misinterpreting Thucydides' words, erroneously link Ameinocles to construction of the first triremes. ${ }^{32}$ In addition, Thucydides' outlook on the described events indicates that he merely recorded a tradition the authenticity of which he may have doubted, yet other authors and scholars took his hesitation for surety and uncritically copied his opinions. Therefore, current studies on ancient Greek shipbuilding set the mid-6th century BCE as the period when triremes appeared in Greek fleets. As I shall demonstrate, Polycrates holds a very important place in the development of shipbuilding, since this dating coincides with his shipbuilding programme.

As I have already mentioned, Herodotus narrates that Polycrates sent a group of rebellious Samians to King Cambyses II onboard 40 triremes, ${ }^{33}$ with this information

26 Curtius $1878,258-259$.

27 Haas 1985, 34; Meyer 2012, 133-134.

28 Pagès 2001, 96: Thucydide emploie naus qui veut dire „,navire de guerre”.

29 Starr 1978, 345.

30 Cf. $L S J$, s.v. vaṽ .

31 Thuc. 1.13.

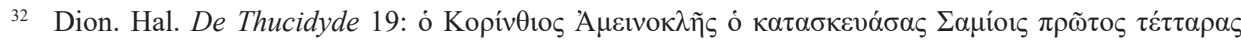

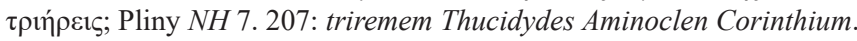

33 Hdt. 3.44; cf. Nowag 1983, 117-124. 
sometimes taken as evidence that the Samian tyrant was probably the first Greek to have triremes in his fleet. ${ }^{34}$ The political upheaval of the mid-6th century BCE-namely, the Persian interference in Asia Minor - could have indeed expedited the concurrent development of military ships in the eastern part of the Mediterranean Sea, ${ }^{35}$ with the resultant transition from older penteconters to newer triremes. However, scholars remain divided on whether Polycrates introduced triremes to the Greek world. Some claim that it would be inconsistent to mention older and newer types of ships, triremes along with penteconters, in a single chapter (3.39). ${ }^{36}$ Such an argument stems from a misunderstanding of the naval vessel turnover rate. The mid-6th century BCE, i.e. Polycrates' floruit, most probably saw the introduction of triremes and very gradual withdrawal of penteconters: any navy could have included both types of vessels. Other scholars claim that if Polycrates was indeed the first Greek ruler to own triremes, it is unlikely that he would have been able to build so many of them, over a short period of time, that he could send forty of them away, ${ }^{37}$ but it is unknown whether Polycrates had built, bought or otherwise acquired triremes. Yet another subset of scholars claims that Herodotus' $\tau \rho \varphi^{\prime} \rho \eta \varsigma^{\text {in chapter }}$ 3.44 denotes not a three-banked ship sensu stricto but an unspecified warship. ${ }^{38}$ This reading fails to acknowledge that Herodotus is more likely to use the general term vaṽ $\varsigma$ when speaking of unspecified vessels. Relevantly, the author of The Histories uses both

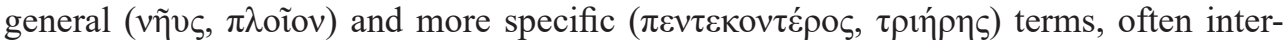
changeably. ${ }^{39}$ For example, when discussing the battle of Lade in 494 BCE, Herodotus describes the Ionian naval force by using a more general $v \tilde{\eta} v \varsigma$, although in this case he clearly meant triremes; ${ }^{40}$ yet, when using specific terms, he never confuses penteconters and triremes. Herodotus' conscious use of naval terminology underlies the passage about the Athenians and the Eritreans sending help to the rebels in Ionia: oil $\tau \varepsilon$ A $\theta \eta v \alpha$ ĩor

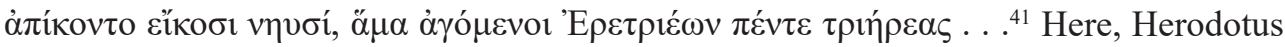
conspicuously juxtaposes two naval terms, with $\tau \rho \imath \rho^{\prime} \eta \varsigma$ clearly set in context of the gen-

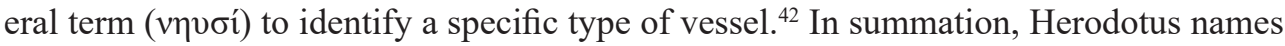
the triremes only when referring to this specific type of a vessel.

The scholarly debate about triremes in Polycrates' fleet centres around the question whether he was the first Greek to use this type of ship or not; however, I argue that a more productive approach would be not to ask whether he was the first Greek to use them but whether he used them at all—and, if yes, how he built/obtained and maintained them. A group of scholars adopted a similar outlook and, accepting that Polycrates had owned triremes, refused to argue for or against him being a pioneer in this regard. One such scholar, Christopher Haas, convincingly argued in his article that Polycrates

34 Davison 1947, 18-24.

35 De Souza 2013.

36 How - Wells 1961, I, 268.

37 Morrison - Williams 1968, 130.

38 Murray - Moreno 2007, 443.

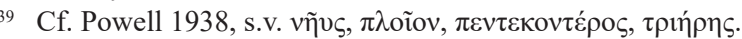

40 Herodotus himself specifies, having described the levies of individual Ionian poleis, that the entire Greek force had 353 triremes; cf. Hdt. 6.8.

41 Hdt. 5.99.

42 Morrison - Williams 1968, 128-129. 
started to build triremes in the face of the growing Persian threat. ${ }^{43}$ Following Haas, I intend to sidestep debates concerning Polycrates' naval innovation: the surviving sources suggest that the tyrant used triremes but was not the first Samian to do so. In my opinion, the ongoing debate about Polycrates' role in introducing triremes to the Greek world ignores one significant aspect of the Greek historiography-namely, linking outstanding achievements to outstanding personages (the authorship myth). The Greeks delighted in crafting tall tales that ascribed significant political and social accomplishments to historic characters, such as Solon the Athenian. In other words, progress could never be a work of anonymous actors: only exceptional figures could perform exceptional deeds. This fallacy obscured the nature of progress as-is - an incremental, collective and often anonymous drive towards complexity. Since few sources survive from the archaic period, such legends of exceptional characters became very difficult to disprove, in time acquired credibility and ultimately found their way in literary accounts of the past. Such might have been the story of Polycrates, unquestionably the best-known ruler of Samos, who started to be credited with accomplishments that were not necessarily his. ${ }^{44}$ The post-archaic shift towards attributing great works to Polycrates can be observed when we contrast Herodotus and Aristotle's accounts on famous Samian works of architecture, the temple of Hera and the tunnel of Eupalinus. Herodotus did not link the mentioned works to Polycrates (3.60), simply stating that they were Samian works, whereas Aristotle (Pol.

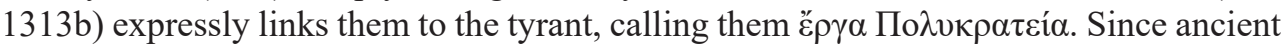
writers tend to ascribe famous works to famous figures, Polycrates' thalassocracy perhaps should be redefined as the Samian thalassocracy under Polycrates.

Relevantly, the development of the Samian fleet could have started under Polycrates' predecessors, as implied by the so-called List of Thalassocracies, preserved in Eusebius of Caesarea's Chronicle and, apparently, excerpted from a work by Diodorus of Sicily. ${ }^{45}$ Scholars disagree about dating the original list, with some inclined to date it to the 5th century BCE and more cautious ones suggesting the Hellenistic period. ${ }^{46}$ Unfortunately, the List of Thalassocracies in particular and the Greek original of Eusebius' Chronicle in general survive only in fragments, ${ }^{47}$ but the List of Thalassocracies itself has survived in Latin and Armenian translations. ${ }^{48}$ Enumerating seventeen non-Greek and Greek peoples who supposedly ruled the Aegean Sea from the sacking of Troy until Xerxes' invasion, ${ }^{49}$ the Armenian version of the list orders the final thalassocrats as follows:

43 Haas 1985, 38.

44 Cf. e.g. Murray - Morreno 2007, 455.

45 The author of Biblioteca Historica points the reader to his list of thalassocrats when telling the story of Minos and non-Greek peoples ruling the Aegean Sea (Diod. 5.84), but Diodorus' list must have been contained in the books which have not survived (6-9). Perhaps Diodorus of Sicily excerpted his list from

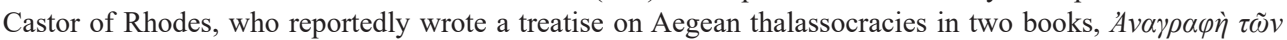

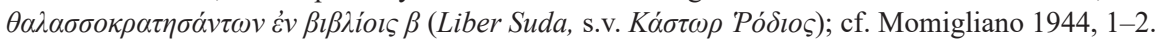

46 Divergent interpretations in dating the duration of naval hegemonies in the List of Thalassocracies were one of the reasons why a bitter dispute erupted between J. Myres and J. K. Fotheringham in the Journal of Hellenic Studies in the early 20th century.

47 Fragments of the Chronicle have survived in Latin, Syrian, and Armenian versions. For more information on the textual tradition of the Chronicle and its versions, see Mosshammer 1979, 29-84.

48 For more information, see Miller 1971, 5-22.

49 Not all codices end with Xerxes; some variants of the manuscript tradition state that the list included rulers up to Alexander the Great and his expedition to Persia. Nevertheless, versions including post-Xerxes 


$\begin{array}{ll}\text { XI. Lesbii. } & \text { ann. (...) } \\ \text { XII. Phokaei. } & \text { ann. XLIV. } \\ \text { XIII. Samii. } & \text { ann. (...) } \\ \text { XIV. Lakedemonii. } & \text { ann. II. } \\ \text { XV. Naxii. } & \text { ann. X. } \\ \text { XVI. Eretrii. } & \text { ann. XV. } \\ \text { XVII. Eginenses. } & \text { ann. X. }{ }^{50}\end{array}$

Interpreting the list to ascribe specific dates to thalassocracies poses difficulty when it comes to the Samians, since their entry is marred with a lacuna. Assuming that the list ends with Xerxes' expedition and the author dates this event to $480 \mathrm{BCE},{ }^{51}$ I subtract the duration of last four thalassocracies (37 years) up to the beginning of the Spartan hegemony; therefore, the Samian thalassocracy would end in 517 BCE. Since the text is badly damaged, other sources are needed to cross-reference dates and corroborate data drawn from The List.

According to The List, the Samians won thalassocracy from the Phocians, hence we first need to determine the duration of the Phocian naval supremacy in the Aegean. Renowned as experienced sailors and intrepid navigators, the Phocians in the Herodotean tradition were the first Greeks to set off on long sea voyages; ${ }^{52}$ Thucydides repeats Herodotus' words and adds that the Phocians settled a colony which they named Massilia (present-day Marseilles). ${ }^{53}$ Scholars have traditionally dated the handover of thalassocracy from the Phocians to the Samians to 533 or $534 \mathrm{BCE},{ }^{54}$ conflating this event with the commonly accepted date of Polycrates' assumption of power on Samos as recorded

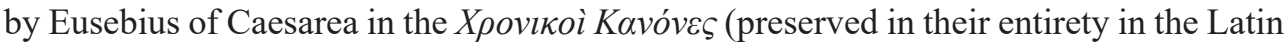
translation of Saint Jerome), i.e. the second part of the Chronicle. ${ }^{55}$ This universal (and erroneous) conflation between the Samian thalassocracy and Polycrates' rule, shared by ancient and modern authorities alike, perpetuates the abovementioned ancient conviction that only great personages could perform great deeds. Nevertheless, surviving sources indicate that the Phocians could not have controlled the Greek seas in the 530s, since it seems unlikely that the Persians, who appeared in Asia Minor in the 540s, would let the Phocians rule over the strategically important Aegean. The end of the Phocian thalassocracy most probably coincided with or resulted from Cyrus II's victory over Lydia in the early 540s, when the Achaemenid Empire subjugated coastal poleis in Asia Minor. The resultant upheaval created a favourable set of circumstances for the Samians to develop their shipbuilding craft, hence dating the beginning of the Samian thalassocracy to the Persian conquest.

Having examined abovementioned sources, I propose that at least a short interval of time had passed between the early 540s, when the Samians seized thalassocracy on

rulers probably contained a scribal error: the following part of the Chronicle concerns Macedonia and the copyist may have mistakenly written Alexander's name instead of Xerxes'; cf. Miller 1971, 5-6.

50 The fragment is quoted in Eusebii Chronicorum Liber Priori, ed. A. Schoene, Berolini 1875.

51 Hammond 1988, 546-547; Briant 2002, 528-530.

52 Hdt. 1.163.

53 Thuc. 1.13 .

54 Cf. e.g. Myres 1906, 102-103; Helm 1926, 252; How - Wells 1961, I, 127; Miller 1971, 106-107; Murray - Moreno 2007, 184.

55 Eus. Chron. 185 F Helm. 
the Aegean, and the beginning of Polycrates' reign (ca 540-535 BCE). In result, we can conclude that the first triremes could have appeared in the Samian fleet in the late 540s BCE, even before Polycrates' coup. If it had been so, then Samos, as an affluent polis famous for its ships, could have easily built or acquired 40 Herodotean triremes within a twenty-year interval between the 540s and 520s, even if some scholars have doubted Samos' potential in that aspect. ${ }^{56}$

At this point, I need to address yet another scholarly misconception concerning the presence of triremes in Polycrates' fleet. Morrison and William, authors of the Greek Oared Ships 900-322 B.C., maintain that Polycrates would not have given away his entire fleet of 40 triremes to carry away the rebellious Samians. Nevertheless, careful analysis of sources demonstrates that 40 triremes mentioned by Herodotus might have been almost all ships of that type in Polycrates' fleet. The political and financial situation of Samos as described chapter 3.44 of The Histories (the eve of Cambyses II's invasion of Egypt, ca $525 \mathrm{BCE}$ ) had been gradually deteriorating. ${ }^{57}$ Polycrates, who died in 522 BCE, experienced increasing difficulties at home and abroad towards the end of his reign. The Achaemenid Empire continued to strengthen its position in the eastern Mediterranean, increasingly restricting freedoms of nominally independent islander Ionians. Simultaneously, Samos came under attack of the Lacedaemonians, as relayed by Herodotus. ${ }^{58}$ By the mid-520s, Polycrates could no longer pursue his ambitious policies (which probably included privateering and banditry to earn his fleet's upkeep) with the same intensity as at the beginning of his reign. The limited ability to set out on raids and dwindling maintenance funds could have angered mercenary forces in the fleet and turned them against Polycrates. In view of the above, I argue that, by mid-520s, maintaining 40 triremes became a luxury Polycrates could no longer afford, which is why he sent the ships away to Cambyses II, so that their upkeep would become the Persian responsibility and deplete Persian resources. If we accept this interpretation, then Polycrates' dismissal of 40 triremes in chapter 3.44 of The Histories could be read as a shrewd strategy to remove potentially rebellious sailors from his land. ${ }^{59}$

\subsection{The samaina, Its Features and Use}

Writing on the fleet of the most famous Samian tyrant, it is impossible not to mention a mysterious type of Samian ship with a boar-shaped prow about which the classical literary sources (Herodotus, Cratinus and Choerilus) provide only a few bare details. This fast and manoeuvrable ship, so-called the samaina by the later tradition, probably played a significant role in the Samian fleet in the 6th century BCE. Herodotus (3.59) relays the earliest description of this type of ship when describing a sea battle between the Samians and joint forces of the Aeginetans and Cretans, at the end of the 6th century: ${ }^{60}$

56 Morrison - Williams 1968, 130.

57 Cf. e.g. Kienitz 1953, 55-66; Briant 2002, 31-61.

58 Hdt. 3.39.

59 For the high cost of maintaining triremes in the context of Polycrates' fleet, see: Morrison - Coates Rankov 2000, 40-41.

60 Murray - Moreno 2007, 454. 
... but in the sixth year Aeginetans and Cretans came and defeated them [the Samians - J. K.] in a sea-fight and made slaves of them; moreover, they cut off the ships' prows, that were shaped like boars' heads, and dedicated them in the temple of Athena in Aegina.

The description above specifies that the Samian ships had prows shaped like boars' heads; this characteristic feature of the so-called samaina will consistently appear in other sources. Unfortunately, Herodotus' description, like other early sources on the $s a$ maina, does not indicate the character of the ship: since Herodotus mentions it in the context of a sea battle, it was used for military purposes. ${ }^{61}$ Other early sources (5th century BCE) on the samaina survive only as excerpts in Photios' Lexicon: under the entry $\Sigma \alpha \mu 1 \alpha \kappa o ̀ v \tau \rho o ́ \pi o v$, Photios stresses the unusual appearance of the samaina's prow, citing lines from the comic poet Cratinus and Choerilus of Samos.

Our limited data on the samaina, drawn from Herodotus, Cratinus and Choerilus, allow us to reach very few conclusions. Conspicuously, the earliest extant tradition on the samaina does not in any way address its technical specifications or intended use. None of the quoted writers link the samaina to Polycrates, although we cannot be certain about Cratinus and Choerilus, since their works survive only in fragments. The historical context of these references dates the use of samainae to the late 6th (Herodotus) and, probably, the 5th (Cratinus and Choerilus) centuries BCE, although Choerilus' testimony may reflect an earlier period in time. What all three writers agree on is the appearance of the samaina, said to resemble a boar's head. The textual evidence on the samaina's appearance matches its numismatic depictions (Fig. 1A-B) ${ }^{62}$

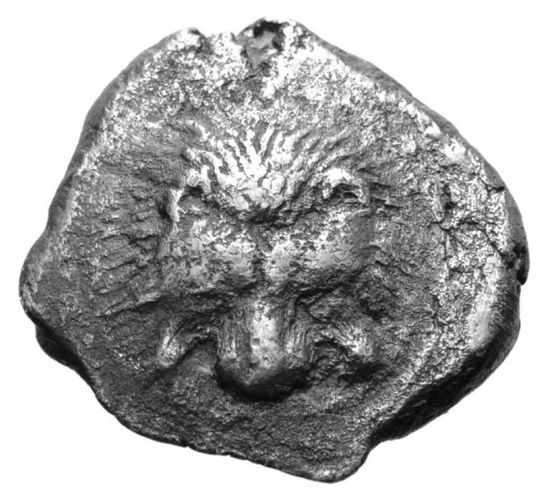

A

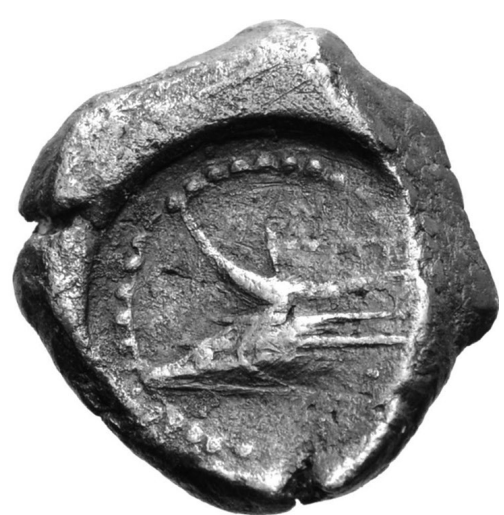

$\mathrm{B}$

Fig. 1A-B. Sicily, Messana (as Zankle) AR Diobol. Samian occupation, 493-488 BC

As I have stressed, the earliest surviving information about the samaina (including Herodotus' account) focuses on its distinctive appearance. Later accounts that provide

${ }^{61}$ It is worth noting that Aideen Carty, the author of the only (and otherwise commendably thorough) monograph on Polycrates, devotes around three pages to the samaina but does not include the quoted passage from Herodotus, or any other sources from the 5th century; cf. Carty 2015, 141-144.

62 E.g. Gardner 1892, 13-20; Barron 1966; Morello 2012, 19-34. 
us with more detailed data pose certain interpretative problems, as evidenced by the following fragment of the Liber Suda (s.v. $\Sigma \alpha \mu i ́ \omega v \delta \tilde{\eta} \mu о \varsigma)$ :

... while the Athenians tattooed the Samians captured in war with an owl, the Samians [tattooed the Athenians] with a Samaina (it is a two-banked ship built first by Polykrates, the Samian tyrant, as Lysimachos [says] in Book 2 of Returns). And the fiction [is] Douris's. But some say the Samaina is a coin. ${ }^{63}$

The fragment above, a compilation of several different traditions, claims that the tyrant Polycrates initiated the construction of the samaina, a two-banked ship, which the Samians adopted as their symbol and tattooed on their Athenian prisoners of war. What is problematic is the identification and contextual analysis of sources named in this passage: Duris of Samos (4th-3rd century BCE) and the rhetorician Lysimachus (3rd-2nd century BCE). ${ }^{64}$ Felix Jacoby simultaneously identifies the quoted passage of the Liber Suda as a fragment of Duris (FGrH 76 F 66c) and Lysimachus (FGrH 382 F 7). Nonetheless, the passage visibly frays into strands taken from different sources: Lysimachus conveyed that the samaina, a two-banked ship built on Polycrates' orders, was used by the Samians as a symbol to brand the captured Athenians, whereas Duris identified the samaina with a coin. Should we separate the passage in such a manner, then Lysimachus' Returns would be the first surviving work to mention any technical specifications of the samaina (a two-banked ship), to link the ship's construction to Polycrates, as well as to mention the tattooing of the Athenian prisoners. Duris, on the other hand, would have been the first author to use the name 'samaina'. This Sicilian-born Samian historian ${ }^{65}$

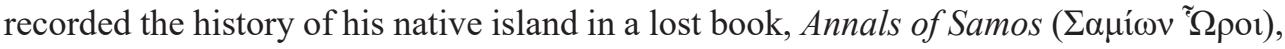
with Jacoby classifying the passage in the Liber of Suda as a fragment of this work. The

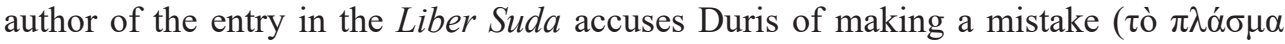

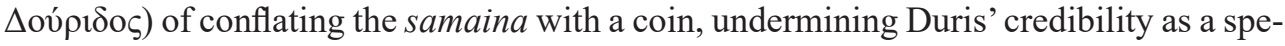
cialist on Samian affairs. One plausible interpretation of this passage is that the samaina was no longer built at the turn of the 4th and 3rd centuries and was hence a little known type of ship, even among those who specialised in naval warfare. The coinage depicting this type of a ship could have been commonly called 'samainae', just as the Athenian drachma was commonly known as 'an owl', after the image of a bird impressed upon it. A competing interpretation is that the samaina could have been placed on Samian coins long after it ceased to be built, so many in the later period would associate samaina with coinage and not with ships, since they would have never seen the coin's namesake.

Between these two interpretations, the evidence found in fragments of Alexis of Samos indicates that even Samian authors writing about Samian affairs knew little on the topic of the samaina. Alexis of Samos ( FGrH 539), who probably lived later than Duris,

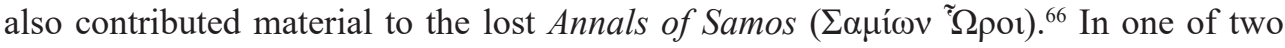

63 Translation by G. Shipley, http://www.stoa.org/sol/ (accessed: 12 March 2018).

64 For more information on Duris of Samos, see e.g.: Kebric 1977; Gattioni 1997; for Lysimachus, see e.g. DNP, s.v. Lysimachos.

${ }^{65}$ Although Duris was born on Sicily in a family of Samian political émigrés, he returned to his native island in his childhood.

66 Unfortunately, almost nothing is known about Alexis of Samos, the chronology of his life or authored works. It is conjectured that he may have lived and worked at the turn of the 3rd and 2nd century BCE. Surviving fragments of the Annals of Samos indicate that the work divided into at least three books: what little 


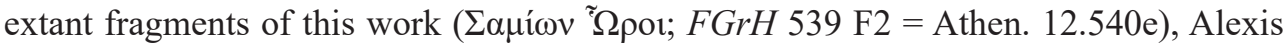
records the information that 'Polycrates was the first man who called the ships which he had built Samians, in honour of his country' ${ }^{67}$ Apart from this passage, Alexis does not

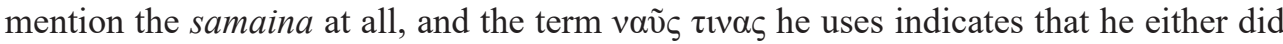
not know any details about this type of ship or he deemed it insignificant.

Another two pieces of evidence on the samaina's construction come respectively from Plutarch and Hesychius of Alexandria. Plutarch's Life of Pericles (Plut. Per. 26) repeats information found in The Liber of Suda and Alexis of Samos, attributing the construction of the samaina to Polycrates and narrating the story about Athenian prisoners. Nevertheless, Plutarch omits the information about the samaina being a two-banked ship, instead focusing on its appearance; the ship supposedly had an upturned prow resembling a boar's head, and a wide and bulky hull. Plutarch then appends an information unknown from earlier accounts, stating that this type of vessel was very capacious and swift. ${ }^{68}$ In turn, an entry from Hesychius of Alexandria's Lexicon provides related information on this type of ship: ${ }^{69}$

Didymus [claims] that the Samainae have a similar built to other ships. But they had a wider belly.

The prow was upturned, it seems, shaped like a boar's snout. That is why it is said that the swift Samaina ship looked like a boar.

Scholars have attempted to reconstruct the samaina's appearance and technical specifications on the basis of numismatic material and the written sources discussed above. Another useful comparand, the ship-shaped votive offerings donated to the Samian Heraion have also been employed to reconstruct the samaina's build..$^{70}$ To bring the review of sources on the samaina to a satisfactory conclusion, I can add that it most probably was a ship with two banks of twenty-five oars, ${ }^{71}$ exceptionally capacious, broad-bellied, yet manoeuvrable and fast.

Having considered the samaina's build, I now turn to examine its role in Polycrates' fleet in light of political changes that came after the Persian expansion in Asia Minor. The southern Aegean Sea, where Samos lies, witnessed some momentous events in the second half of the 6th century BCE. The Achaemenid empire's conquest of the Greek poleis in Asia Minor disturbed the balance in the region, posing a direct threat to Greekinhabited Aegean isles yet also opening up favourable opportunities for the islanders. ${ }^{72}$

remains of it also tells of Polycrates' love of luxury. Since Alexis mentions Polycrates in book III and Pericles in book II, the Annals probably did not have a linear structure but contained digressions; cf. RE, s.v. Alexis (10); BNJ 539 (Commentaries).

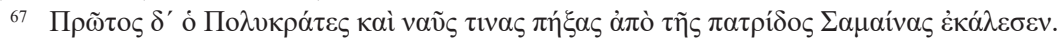

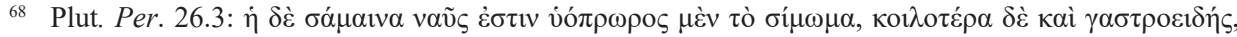

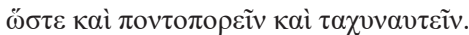

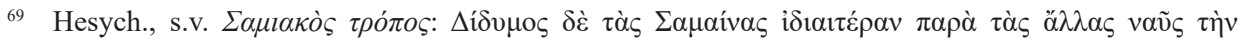

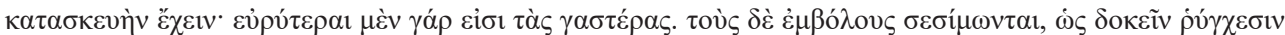

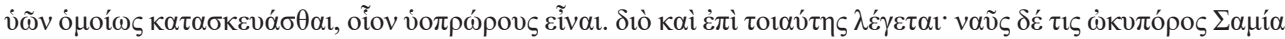

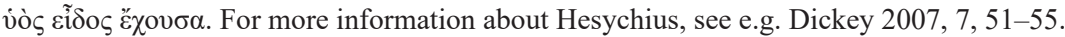

70 Study on Ancient Ship of Samaina 2008, 6-7; for the Samian Heraion, see e.g. Kyrieleis 1993, 99-123.

71 Study on Ancient Ship of Samaina 2008, 7.

72 Herodotus writes about the Persian conquest of the Aegean in his Histories. We should, however, draw attention to some inconsistencies in his account. The historian mentions that the Ionians on the islands, fearing the fate that met the mainland Ionians, surrendered to Cyrus (Hdt. 1.169). In another chapter (1.143) 
Following the Persian invasion, the Phocians, described by Herodotus as experienced sailors, somehow lost a significant portion of their navy, bringing only three ships to the battle of Lade in 494 BCE. ${ }^{73}$ The diminishment of the Phocian naval power created an excellent opportunity for the islander Ionians, such as the Samians, to seize the dominion over the seas. Nevertheless, this political upheaval in the Aegean after the Persian conquest, although exploitable, created new problems for Polycrates, who had to operate in rather disadvantageous circumstances and manoeuvre between waning yet still formidable Egypt and newly ascendant Persia. ${ }^{74}$ Samos' problems abroad included warlike Greek poleis, with the Lacedaemonians organising an unsuccessful military expedition against Polycrates. ${ }^{75}$ Trouble was also brewing at home on Samos, where the established aristocracy actively opposed Polycrates' tyranny. ${ }^{76}$ Bearing in mind Polycrates' deteriorating circumstances, it becomes clear that including samainae in his fleet could offer Polycrates' a significant and much needed advantage. When danger arises on all sides, at home and abroad, one needs a quick, manoeuvrable and capacious ship, efficiently transporting goods and soldiers between islands. Although it remains uncertain whether the samaina was a warship or a mixed-use vessel, we can assume that it could take a considerable number of mercenaries onboard. ${ }^{77}$

Significantly, the use of samaina ships could have boosted the Samian trade and economy, since their capacious hull could carry large amounts of goods and their speed could make them suitable for carrying out raids. Alexis of Samos, whom I mentioned above, relates that in Polycrates' times Samos obtained many goods from numerous po-

Herodotus relates that neither the Milesians nor islander Ionians had to fear the Persians: the Milesians had

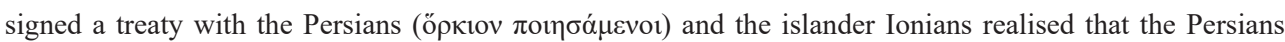
could not attack them, since they had no navy and, at that point in time, could not use the still-independent Phoenician sea force. No other source indicates that the Persian conquest of the poleis in Asia Minor led to the subjugation of the Aegean islands; in facts, these islands, ruled by local pro-Persian tyrants, generally supported the Persians; see Murray - Moreno 2007, 189.

73 Hdt. 6.8. Notably, later sources, such as the List of Thalassocracies preserved by Eusebius of Caesarea, enumerate the Samian thalassocrats after the Phocians. Wallinga 1984 provides further information on that subject.

74 It seems likely that Polycrates at the beginning of his rule allied himself with Egypt. From the 7th century BCE onwards, Egypt and the Greek poleis established harmonious relations; the Samians maintained a constant presence in Naucratis, the Greek colony in Egypt, where they enjoyed a right to have their own temple (Hdt. 2.178, for more on Naucratis, see Möller 2000). At one point, the relationship between Egypt and Samos soured, as retold in the famous tale about Polycrates' ring: pharaoh Amasis supposedly broke

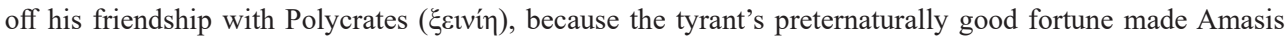
fear that Polycrates would eventually meet a tragic end and perhaps draw Amasis along. The story is mainly known from Herodotus' Histories (Hdt. 3.40-43), but it is also mentioned by Strabo (14.16). Diodorus of Sicily (Diod. 1.95) relays a more rational version, stating that Amasis broke off his friendship with Polycrates because he disliked his overly oppressive internal policy. Some scholars have proposed interesting reinterpretations of their relationship, claiming that it was Polycrates who broke off the alliance; cf. Austin 1990, 297-298.

75 Hdt. 3.54-56; Sparta's actions against the tyrants are also mentioned by Plutarch in De Herodoti Malignitate (Plut. De Herod. 21, 859 C-D).

76 Hdt. 3.44-45; the strong position of Samian aristocrats is hinted at by Herodotus' note that Polycrates

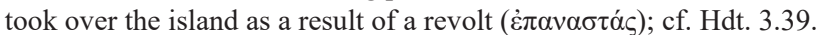

77 For the military nature of the samaina, see Shipley 1987, 81; against it, see Wallinga (1993, 93-102), who presumes that Polycrates was involved in large-scale transport of Egyptian mercenaries to the Aegean. 
leis across the Aegean, including dogs from Molos and Laconia, goats from Skyros and Naxos, and cattle from Miletus and Africa. ${ }^{78}$ The fleet of samainae presumably helped Polycrates to ship such goods quickly and efficiently. Relevantly, Polycrates most probably engaged not only in trade but also in what we could call piracy, pillaging coastal communities of the Aegean for financial gain; ${ }^{79}$ indeed, Herodotus confirms that Polycrates' fleet indiscriminately raided many settlements. ${ }^{80}$ Pirate raids probably provided for the bulk of Polycrates' extraordinary fortune, extolled as legendary already by the writers of classical Greece. ${ }^{81}$ Samainae, fast ships with capacious hulls, were perfect both for the Aegean trade and for raids, bringing quick profits. Interestingly, some scholars postulate that Polycrates perhaps engaged in coastal raids to follow the example of his father, Aeaces. ${ }^{82}$ The sources which mention Polycrates' naval activity corroborate that the tyrant preferred to raid territories instead of fully subjugating them politically. When Herodotus mentions that Polycrates captured numerous islands in the vicinity of Samos and some territories on the mainland, he most probably refers to piracy, ${ }^{83}$ since the Persian presence in Asia Minor made any Samian territorial acquisitions on the continent rather unlikely ${ }^{84}$ and no information survives about any Aegean islands being lastingly included into the Samian domain. ${ }^{85}$ In contrast to Herodotus, Thucydides conveys

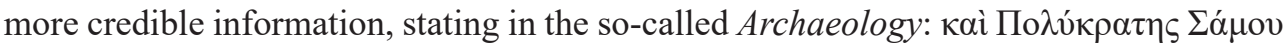

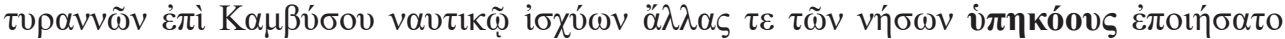

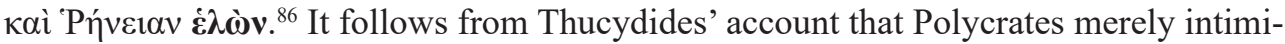
dated or raided nearby islands, but he did not make them subject to him. ${ }^{87}$ One possible exception could be the island of Rhenea near Delos, which, according to Thucydides, had been conquered by Polycrates. Highlighting this particular island in the text would suggest that this was Polycrates' only territorial acquisition. ${ }^{88} \mathrm{I}$ surmise that Polycrates controlled these territories insofar as he deemed necessary to extort his tribute, with surviving sources signalling that other Greek tyrants of the archaic period also coerced

78 BNJ 539 = Aten. 10.540d. The Athenian Clytus relates similar information, although his account is palpably biased against Polycrates, since, in Clytus' view, the tyrant brought all these goods to Samos solely

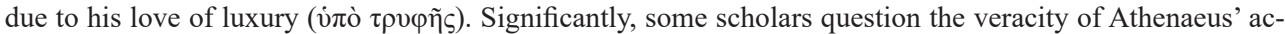
count, see Günther 1999.

79 Heichelheim - Stevens 1958, 260-261.

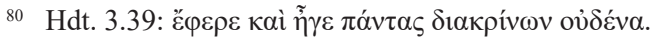

81 Plat. Meno 90a.

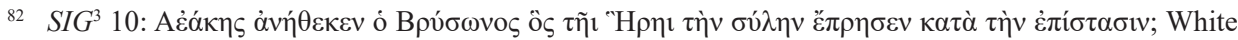
1954, 38; Barron 1964, 218; Tölle-Kastenbein 1976, 30-32.

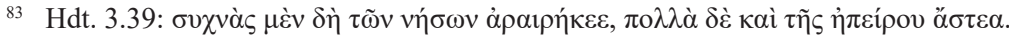

84 Murray - Moreno 2007, 440.

85 Some scholars maintained that Polycrates ruled Rhodes by appointing his son of the same name as his local representative; however, this hypothesis is based on the late and rather damaged account excerpted from Himerius' Orationes; cf. Bowra 1934, 375-380.

86 Thuc. 1.13 .

87 Other passages from Thucydides' work referring to to the Athenian $v \pi \varepsilon \kappa o ́ o 1$, the historian writes (4.57.3) that they may have been partly independent - $\xi 0 \mu \mu \alpha \chi \alpha \varsigma$

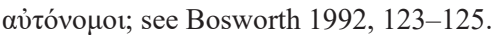

88 Ure 1906, 132. 
their neighbours. ${ }^{89}$ Should we accept that Polycrates' naval and fiscal policy depended on raiding surrounding coasts, then samainae could have played a significant role in these endeavours.

\section{The Number of Ships in Polycrates' Fleet}

The only source which specifies the number of ships in Polycrates' fleet is Herodotus' Histories, but interpreting the numerical data recorded there presents a considerable challenge for scholars. Herodotus at times appears to inflate the given numbers to an implausible size: in the passage about Xerxes' army, he claims that it numbered a hundred and seventy myriad, i.e. 1,700,000 men. ${ }^{90}$ Furthermore, Herodotus frequently gives so-called 'typical' or 'conventional' numbers, symbolically important multiples of certain numbers such as 3,7 or 9 , such numbers constituting approximately half of the numerical data contained within The Histories. ${ }^{91}$ Every now and then, Herodotus inaccurately calculates or estimates certain numbers and values. ${ }^{92}$ Regarding the subject of this article, I acknowledge that Herodotus provides skewed data on the size of the fleets, since some numbers given by him belong to a 'typical' class. For example, the historian claims that the Persian fleet launched 600 ships, both during Darius' Scythian expedition in 513 and during the Battle of Lade in $494 .{ }^{93}$ Scholars, including commentators on The Histories, unanimously question the accuracy of this round number, pointing out that it is a conventional one. ${ }^{94}$ Nevertheless, Herodotus occasionally records odd numbers that appear accurate, with some of them confirmed by other sources. In case of the Persian contingent in the battle of Salamina, Herodotus maintains that it numbered exactly 1,207 triremes, ${ }^{95}$ whereas Aeschylus gives precisely the same number in The Persians, in the line spoken by a messenger addressing Atossa. ${ }^{96}$

Taking into consideration the Herodotean approach towards numbers, we encounter two problems when estimating the size of Polycrates' navy. The first problem concerns our understanding of Herodotus' inconclusive information about Polycrates having 100 penteconters and 40 triremes at his disposal. ${ }^{97}$ The analysed fragment is open to two plausible interpretations: we either add up the data from two passages (140 ships in total) or we acknowledge only the first piece of information (100 vessels) as the total of Polycrates' naval forces. Regardless of which interpretation we choose, both numbers

89 For example, Herodotus mentions the raid of Histiaeus of Miletus, who went to Mysia to seize grain for his army, see Hdt. 6.28.

90 Hdt. 7.60; cf. e.g. How - Wells 1961, II, 151; Rubincam 2003, 454.

91 Rubincam 2003, 458-459; for typical numbers in Herodotus' Histories, see also Fehling 1971, $155-168$.

92 Keyser 1986, 230-242.

93 Hdt. 4.87; 6.8 .

94 How - Wells 1961 I, 333; Hignett 1963, 347-348; MacQueen 2000, 90; Scott 2005, 108; Murray Moreno 2007, 644.

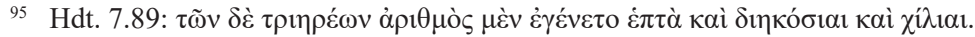

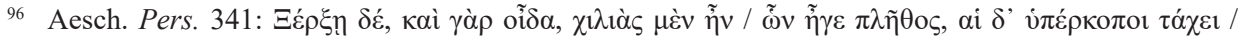

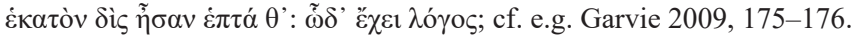

97 Hdt. 3.39; 3.44. 
(100 and 140) appear conventional. Within the text of The Histories (and within the entire surviving body of archaeological and textual evidence ${ }^{98}$ ), the only other source commenting on the size of the Samian fleet is the Herodotean account on the battle of Lade (494 BCE).$^{99}$ The historian claims that the Ionians had 353 vessels at their disposal, out of which 60 were brought by the Samians. In this case, Herodotus also might have rounded off the number of the Samian ships. ${ }^{100}$ The accuracy of this account notwithstanding, I use Herodotus' data on the battle of Lade (494 BCE) to estimate how many ships might have sailed in Polycrates' fleet (ca. 540-520 BCE).

The battle of Lade between the Persians and the Ionians in 494 BCE coincided with a difficult period for Samos, beset by internal problems and increasingly subjugated by the Achaemenid Empire. ${ }^{101}$ The Samian troubles at home and abroad probably limited the Samians' ability to maintain a large fleet. Should we accept Herodotus' number about 60 Samian ships at Lade (with a proviso that the number might have been rounded off), then the size of Polycrates' fleet in the 520s (100-140 vessels) also appears appropriate: if the troubled Samos could outfit 60 ships in 494, then the well-maintained and affluent Samos under Polycrates' reign could easily outfit more than 100 ships. The literary and archaeological sources indicate that Polycrates' rule coincided with Samos' floruit, when the island still enjoyed its independence from Persia. Additionally, I have demonstrated that Polycrates' economic policies and the need to defend Samos from internal and external threats necessitated maintaining a swift naval response force.

As an aside, the construction and upkeep of Polycrates' fleet could have been facilitated by the favourable natural conditions on Samos, in particular the abundance of forests that provided wood, probably obtained from the wooded mountain in the central

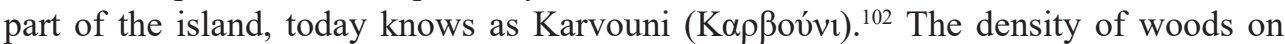
Samos is perhaps reflected in the island's alternative names surviving in ancient literary works (e.g. Aristotle and Pliny), such as Cyparissia ${ }^{103}$ and Dryoussa. ${ }^{104}$ Arguably, these late-attested names might not reflect the actual natural conditions on Samos in the mid6 th century; ${ }^{105}$ nevertheless, the Mediterranean ecological balance in the antiquity generally shifted towards deforestation rather than afforestation, with Samos probably having denser woodland in the archaic period. Unfortunately, we cannot juxtapose the Herodotean numbers with any other contemporary source, which precludes us from looking at Polycrates' fleet in more detail. However, having assessed the provided information,

98 Greaves 2010, 164. No other relevant contemporary sources (archaeological or textual) provide information on Greek fleets of the archaic period: Herodotus' commentary remains our best and only evidence.

99 Hdt. 6.7-18.

100 L. Scott, the author of a historical commentary on Book VI of The Histories, concludes that the numbers of all large contingents, including the Samian one, could have been rounded off; see Scott $2005,92$.

101 Shipley 1987, 103-109.

102 Shipley 1987, 6.

103 Pliny NH 5.135.

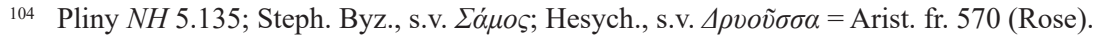

105 These two names are commonly attributed to Aristotle, although I must stress that they are attested only in late fragmentary sources (fr. 570 Rose). Pertinently, out of all the writers believed to have excerpted Aristotle's works on that matter, only Pliny the Elder quotes him as his source (Pliny, NH 5.135): Samon ... Partheniam Primus apellatam Aristoteles tradit, postea Dryusam. 
I feel confident to argue that Polycrates had the capacity to maintain a fleet of approximately 100 ships.

\section{Maintenance}

Without a doubt, fleet maintenance in the archaic period differed from practices of the following periods. As I have mentioned above, the naval forces at Polycrates' disposal belonged to him and not to Samos. Accordingly, the state could not have subsidised the fleet or arranged for any institutionalised form of funding, such as the liturgy of trierachy known from classical Athens and other poleis. ${ }^{106}$ Most likely, Polycrates had to cover all expenses related to maintaining his navy. His legendary wealth suggests that he had the means to afford it. Furthermore, surviving sources, some of which have been discussed above, provide some clues about the methods the tyrant employed to obtain the funds for his fleet.

Polycrates appears to have generated his income from two main sources. First, he deployed his fleet to conduct pirate raids on coastal communities, as mentioned by Herodotus and other writers. ${ }^{107}$ Diodorus of Sicily claims that the tyrant plundered everyone who navigated the seas, ${ }^{108}$ a motif reappearing in a chapter of Polyaenus' Stratagems in War devoted to Polycrates. ${ }^{109}$ Three abovementioned writers set this information in context of a famous saying ascribed to Polycrates, who supposedly stated that 'he would get more thanks if he gave a friend back what he had taken than if he never took it at all' ${ }^{110}$ In all likelihood, Polycrates depended on piracy to maintain his fleet, but this high-risk method of generating income posed a constant threat. If a raid failed and no booty was taken, mercenaries deprived of their loot could mutiny, seize the ships, become independent pirates, deprive the tyrant of a part of his fleet, and rise against his other ships. A similar scenario occurred on the eve of the Ionian revolt of 499, as described by Herodotus: the governor ( $\dot{\varepsilon} \pi i \tau \rho о \pi \circ \varsigma$ ) of Miletus, Aristagoras, decided to rebel because his unsuccessful expedition against Naxos failed to reap expected profits and prevented him from paying off his debts to Persia. ${ }^{111}$ Pillaging did not necessarily happen only at sea. Diodorus of Sicily conveys the story of Lydian refugees who fled to Samos from the satrap Oroetus. Their host, initially kind ( $\varphi \lambda$ $\lambda \circ \varphi \rho o ́ v \omega \varsigma)$, eventually decided to slay

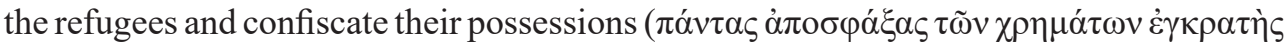
$\dot{\varepsilon} \gamma \varepsilon \dot{\varepsilon} \varepsilon \tau 0) .{ }^{112}$ Although Diodorus' story may have exaggerated Polycrates' perfidiousness

106 Cf. e.g. Gabrielsen 1994.

107 Hdt. 3.39.

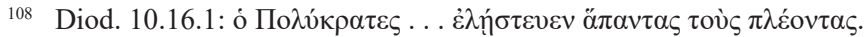

109 Polyaen. 1.23.

110 Hdt. 3.39; Diod. 10.15; Polyaen. 1.23.

111 The Persian Artaphrenes, who provided Aristagoras with 200 ships, was promised great wealth, territorial acquisitions, and reimbursement of all war expenses, cf. Hdt. 5.31; Kuciak 2012, 42-52.

112 Diod. 10.15.1. 
and guile, ${ }^{113}$ it cannot be ruled out that the tyrant did obtain funds for his activity by taking advantage of vulnerable persons in his domain.

The second source of Polycrates' income could have come from funds obtained before he became a tyrant, with some ancient sources providing circumstantial corroborative evidence for this conjecture. Some authors appear to distinguish between Polycrates' inherited and self-raised capital. With regard to inherited funds, this most famous Samian tyrant probably descended from the affluent local aristocracy. Reconstructions of Polycrates' family tree include ancestors who occupied positions of authority on the island in the mid-6th century BCE, such as Syloson I, believed to have been the first Samian tyrant, ${ }^{114}$ and Polycrates' father, Aeaces. Polycrates' father apparently cared deeply about his son's education and invited intellectuals and poets to Samos to educate Polycrates. A rather damaged passage from Himerius' Orationes relates that Polycrates' father (here left unnamed) brought the poet Anacreon to Samos to tutor the future tyrant in the art of government. ${ }^{115}$ Another great poet, Ibycus, is known to have dwelled on Samos at approximately the same time, ${ }^{116}$ producing a poem conventionally titled Ode to Polycrates: ${ }^{117}$ although not all scholars concur on that matter, I contend that Ibycus in all likelihood addressed this panegyric to the future tyrant, foretelling Polycrates' legendary fame. ${ }^{118}$ In order to hire two poets of such great renown, Polycrates' immediate family must have accumulated enormous wealth. Relevantly, Polycrates could have added to his family's funds before he became a tyrant by renting certain assets. A fragment of the $\mathrm{An}$ nals of Samos ( $\Sigma \alpha \mu i \omega^{\prime}$ v $\left.\Omega \rho o l\right)$ authored by Alexis of Samos and surviving in Athenaeus' Deipnosophistae narrates that young Polycrates had ordered artisans to create exquisite rugs and goblets and then leased them to those who held a wedding feast or celebration. ${ }^{119}$ Assuming that this information is credible, it cannot be ruled out that Polycrates generated profits from leasing assets $(\chi \rho \tilde{\eta} \sigma \theta \alpha \imath)$ before seizing power on the island.

Generally speaking, the maintenance of Polycrates' fleet and financing his other ventures demanded Polycrates' constant attention in an unstable environment beset by troubles at home and abroad: one failed venture could easily drain his resources and lock him in a vicious circle of debt. The literary tradition implies that Polycrates' obsessive and proverbial lust for wealth became his end. According to Herodotus, Oroetus, the satrap of Sardes, lured Polycrates into his land with promises of great riches; the greedy tyrant went to Magnesia and was summarily slain by Oroetus. ${ }^{120}$ The Herodotean account seems to overemphasise Polycrates' negative traits in accordance with his black legend. Nevertheless, should we approach Herodotus' account critically and analyse it within the context of Polycrates' precarious financial situation, then we could argue that

113 A similar pattern seems to emerge from a passage of The Histories (3.39), in which Herodotus claims that Polycrates initially ruled the island with his two brothers, only to kill one and banish another.

114 Homann-Wedeking 1953-1954; Barron 1964, 212; Shipley 1987, 68; Murray - Moreno 2007, 439.

115 Him. Orationes 29.

116 Liber Suda, s.v. 'Ißıкos.

117 PMG 282.

118 Sisti 1966, 91-102; West 1970, 205-215; Woodbury 1985, 193-220; Weber 1992, 47-51.

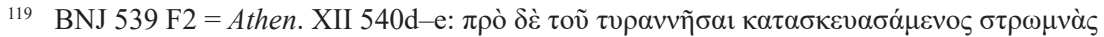

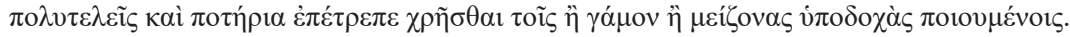

120 Hdt. 3.120-125. The fact that Polycrates was killed as a result of his lust for wealth is also mentioned by Athenaeus, see Athen. 12.540e-f.; cf. Bichler 2007, 13. 
the Samian tyrant may have faced some financial setbacks and came to Oroetus out of necessity - and not out of his love of riches, $\tau \rho \nu \varphi \eta$, as ancient writers would have it. Polycrates' arrival at Oroetus' court might have been purely pragmatic. The tyrant knew that his power would collapse if he did not secure another source of funding for his navy: he hoped to obtain funds from Oroetus, who had never shown any murderous intent towards Polycrates and, in fact, had never even met Polycrates before he had him slain.

To recapitulate, Polycrates paid for his fleet in a fashion similar to how he paid for his other expenses: by trading, pillaging communities across the Aegean and dipping into his private funds. A capable financier, Polycrates must have devoted much time to securing funds for mercenaries at his disposal. His sizeable fleet apparently had to earn its keep through constant raids: every failure to obtain tribute or loot could induce sailors and soldiers to mutiny, a danger Polycrates must have remained aware of.

\section{Conclusions}

My analysis of the available material has demonstrated that Polycrates' navy enabled him to successfully pursue his domestic and international policies; however, this is the only conclusion that can be drawn with a high degree of certainty. The limitations of the source material — in particular, the questionable accuracy of Herodotus' Histories - hinder our attempts at understanding how Polycrates maintained and employed the naval force at his disposal. Having surveyed the extant evidence, I argue that Polycrates paid for his fleet out of his own coffers; to maintain it, he had to actively engage in trade and pirate raids, since his navy's expensive upkeep probably depended on loot obtained during these raids. An astute economist, Polycrates might have also inherited or generated other sources on income. I have also discussed types and numbers of vessels in Polycrates' navy. I postulated that Polycrates probably owned triremes but was not the first Samian to do so; yet, he might have been the first to construct samainae - fast, manoeuvrable and capacious ships that allowed him to navigate between the great powers of the politically divided Aegean. With regard to the fleet's numbers, I showcased that Samos under Polycrates, an island in its heyday, could easily maintain over a hundred ships, the size of this fleet buttressing the Samian thalassocracy.

BIBLIOGRAPHY

Abramenko, A. (1995), Polykrates` Außenpolitik - eine Revision, Klio 77: 35-54.

Andrewes, A. (1956), The Greek Tyrants, London.

Austin, M. M. (1990), Greek Tyrants and the Persians, 546-479 BC, CQ 40: 289-306.

Barron, J. P. (1964), The Six-Century Tyranny at Samos, CQ 14: 210-229.

Barron, J. P. (1966), The Silver Coins of Samos, London. 
Berve, H. (1967), Die Tyrannis bei den Griechen, vol. I-II, München.

Betalli, M. (1995), I mercenari nel mondo greco, Pisa.

Bichler, R. (2007), Herodot und Macht des Geldes, in: R. Rollinger (ed.), Historiographie-Ethnographie-Utopie, vol. I, Wiesbaden: 11-27.

Bosworth, A. B. (1992), Autonomia: The Use and Abuse of the Political Terminology, Studi italiani di filologia classica 10: 122-152.

Bowra, C. M. (1934), Polycrates of Rhodes, CJ 29: 375-380.

Briant, P. (2002), From Cyrus to Alexander: A History of the Persian Empire, Winona Lake.

Burn, A. R. (1984), Persia and the Greeks, London.

Cartledge, P. (1982), Sparta and Samos: A Special Relationship?, CQ 32: 243-265.

Carty, A. (2015), Polycrates, Tyrant of Samos - New Light on Archaic Greece, Stuttgart.

Curtius, E. (1878), Griechische Geschichte, vol. I, Berlin.

Davison, J. A. (1947), The First Greek Triremes, CQ 41: 18-24.

De Libero, L. (1996), Die archaische Tyrannis, Stuttgart.

De Souza, Ph. (1998), Towards Thalassocracy? Archaic Greek Naval Developments, in: N. Fisher, H. van Wees (eds.), Archaic Greece - New Approaches, New Evidence, London: 271-295.

De Souza, Ph. (2013), War at Sea, in: B. Campbell, L. A. Tirtle (eds.), The Oxford Handbook of Warfare in the Classical World, Oxford, www.oxfordhandbooks.com (access: February 2014).

Dickey, E. (2007), Ancient Greek Scholarship: A Guide to Finding, Reading, and Understanding Scholia, Commentaries, Lexica, and Grammatical Treatises, from Their Beginnings to the Byzantine Period, Oxford.

Diesner, H. J. (1959), Die Gestalt des Tyrannen Polykrates bei Herodot, AAntHung 7: 211-219.

Fehling, D. (1971), Die Quellenangaben bei Herodot. Studien zur Erzählkunst Herodots, Berlin-New York.

Gabrielsen, V. (1994), Financing the Athenian Fleet: Public Taxation and Social Relations, Baltimore.

Gammie, J. G. (1986), Herodotus on Kings and Tyrants: Objective Historiography or Conventional Portraiture?, Journal of Near Eastern Studies 45: 171-193.

Gardner, P. (1892), Samos and Samian Coins, London.

Garvie, A. F. (2009): Aeschylus' Persae - with Introduction and Commentary, Oxford.

Gattioni, F. L. (1997), Duride di Samo, Roma.

Göttlicher, A. (2006), Seefahrt in der Antike. Das Schiffswesen bei Herodot, Darmstadt.

Greaves, A. (2010), The Land of Ionia, Oxford.

Günther, L. M. (1999), Alles von überall her... Handel und Tryphe bei Polykrates von Samos, Münsterische Beiträge zur Antike Handelsgeschichte 18: 48-56.

Haas, Ch. J. (1985), Athenian Naval Power before Themistocles, Historia 34: 29-46.

Hammond, N. G. L. (1988), The Expedition of Xerxes, $C A H^{2}$, vol. IV, Cambridge: 518-592.

Harrison, T. (2000), Divinity and History - the Religion of Herodotus, Oxford.

Heichelheim, F. M., Stevens, J. (1958), The Beginnings of Mediterranean Civilization in the Early Iron Age and its Conflict with the Ancient Oriental Economic Pattern (1100-560 B.C.), in: F. M. Heichelheim, J. Stevens (eds.), An Ancient Economic History from the Palaeoelithic Age to the Migration of the Germanic, Slavic and Arabic Nations, vol. I, Leiden: 193-293.

Helm, R. (1926), Die Liste der Thalassokratien in der Chronik des Eusebius, Hermes 61: 241-262.

Hignett, C. (1963), Xerxes Invasion of Greece, Oxford.

Homann-Wedeking, E. (1953-1954), Syloson der Ältere, Archaiologikê Ephemeris 2: 185-191.

How, W. W., Wells, J. (1961), A Commentary on Herodotus, vol. I-II, Oxford.

Katz-Anhalt, E. (2005), Polycrates and His Brothers: Herodotus' Depiction of Fraternal Relationships in the 'Histories', $C W$ 98: 139-152.

Kebric, R. B. (1977), In the Shadow of Macedon: Duris of Samos, Wiesbaden.

Keyser, P. (1986), Errors of Calculations in Herodotus, CJ 81: 230-242.

Kienitz, F. K. (1953), Die politische Geschichte Ägyptens vom 7. bis zum 4. Jahrhundert vor der Zeitwende, Berlin. 
Kuciak, J. (2012), Zdrajca, oportunista czy patriota? Słowo o Histiajosie z Miletu, in: S. Sprawski (ed.), Człowiek w antycznym świecie, Kraków: 35-55.

Kyrieleis, H. (1993), The Heraion at Samos, in: N. Marinatos, R. Hägg (eds.), Greek Sanctuaries: New Approaches, London-New York: 99-123.

Lenschau, T. (1952), Polykrates (1), RE XXI: 1726-1734.

Luraghi, N. (2006), Traders, Pirates, Warriors: The Proto-History of Greek Mercenary Soldiers in the Eastern Mediterranean, Phoenix 60: 21-47.

MacQueen, E. I. (2000), Herodotus, Book VI, Bristol.

Meyer, K. (2012), Samos, die wasserreiche. Die Insel in der antiken Literatur, Möhnesee.

Miller, M. (1971), The Thalassocracies, Studies in Chronography 2, Albany.

Momigliano, A. (1944), Sea-Power in Greek Thought, CR 58: 1-7.

Morello, A. (2012), Samos, Zankle e la Samaina, in: A. Campana, A. Morello (eds.), Samos, Zankle e la Samaina. La nave di Policrate tra Samo e Messina, Cassino.

Morrison, J. S., Coates, J. F., Rankov, N. B. (2000), The Athenian Trireme: The History and Reconstruction of an Ancient Greek Warship, Cambridge.

Morrison, J. S., Williams, R. T. (1968), Greek Oared Ships 900-323 B.C., Cambridge.

Mossé, C. (1969), La tyrannie dans la Grèce antique, Paris.

Mosshammer, A. A. (1979), The Chronicle of Eusebius and Greek Chronographic Tradition, Lewisburg.

Möller, A. (2000), Naukratis: Trade in Archaic Greece, Oxford.

Murray, O., Moreno, A. (eds.) (2007), A Commentary on Herodotus, Books I-IV, Oxford.

Myres, J. L. (1906), On the 'List of Thallasocracies' in Eusebius, JHS 26: 84-130.

Nowag, W. (1983), Raub und Beute in der archaischen Zeit der Griechen, Frankfurt am Main.

Oliva, P. (1954), Raná řecká tyrannis. Studie k otázce vzniku státu, Praha.

Pagès, J. (2001), Recherches sur thalassocraties antiques: L'exemple grec, Paris.

Powell, J. E. (1938), A Lexicon to Herodotus, Cambridge.

Rubincam, C. (2003), Numbers in Greek Poetry and Historiography, CQ 53: 448-463.

Scott, L. (2005), Historical Commentary on Herodotus, Book 6, Leiden.

Shipley, G. (1987), A History of Samos 800-188 BC, Oxford.

Sisti, F. (1966), Ibico e Policrate, QUCC 2: 91-102.

Starr, C. (1978), Thucydides and Sea Power, Mnemosyne 31: 434-350.

Study on Ancient Ship of Samaina (2008), Pythagorio.

Tölle-Kastenbein, R. (1976), Herodot und Samos, Bochum.

Ure, P. (1906), The Origin of the Tyrannis, JHS 26: 131-142.

Van Wees, H. (2013), Ships, Silver, Taxes and Tribute - a Fiscal History of Archaic Athens, London New York.

Wallinga, H. T. (1984), The Ionian Revolt, Mnemosyne 37: 401-437.

Wallinga, H. T. (1993), Ships and Sea Power before the Great Persian War: The Ancestry of the Ancient Trireme, Leiden-New York-Köln.

Weber, G. (1992), Poesie und Poeten an den Höfen vorhellenistischer Monarchen, Klio 74: 25-77.

West, M. (1970), Melica, CQ 20: 205-215.

White, M. (1954), Duration of the Samian Tyranny, JHS 74: 36-43.

Woodbury, L. (1985), Ibycus and Polycrates, Phoenix 39: 193-220. 